\title{
Funk Staden: \\ atualidade do gesto antropofágico
}

\author{
Anita Matilde Silva Leandro ${ }^{1}$ \\ Greice Cohn²
}

\footnotetext{
${ }_{1}^{1}$ Professora da Escola de Comunicação da UFRJ, com mestrado e doutorado em cinema pela Université Paris 3. Foi professora do Nutes-UFRJ e da Universidade de Bordeaux 3. Além de vários artigos sobre cinema, é autora do livro Le personnage mythique au cinéma (Septentrion, 2000) e do filme Retratos de identificação, competição internacional no FID Marseille, premiado no CachoeiraDoc e no Festival latinoamericano de Trieste.

Email: anita.leandro@eco.ufri.br

${ }^{2}$ Greice Cohn é professora Titular de Artes Visuais do Colégio Pedro II (1994-2018), com mestrado e doutorado em educação pela UFRJ. No doutorado (PPGE, 2016) e no mestrado (NUTES, 2004) investigou a pedagogia das imagens em movimento da arte contemporânea no ensino da arte. Realizadora da videoinstalação educativa Ruptura e Tradição: passagens pelo século XIX e XX (2004) e do documentário Ensino da arte: espaço poético (2010), leciona nos cursos de especialização Saberes e Fazeres no Ensino de Artes Visuais (Colégio Pedro II, 2019) e Ensino Contemporâneo de Arte (CESPEB/UFRJ, 2019-2020).

Email: greicecohn@uol.com.br
} 


\section{Resumo}

Em 2012, quando o Centro Municipal de Artes Hélio Oiticica, no Rio de Janeiro, abrigava a exposição Até que a rua nos separe, dos artistas Dias \& Riedweg, um grupo de estudantes do ensino médio visitou o evento. Entre as instalações da exposição, Funk Staden (2007) chamou particularmente a atenção dos alunos pela forma como ela atualizava o tema ancestral da antropofagia, inscrito, desta vez, de maneira ao mesmo tempo lúdica, sensual e violenta, na cultura funk das favelas cariocas. Analisaremos aqui essa obra participativa, com grande potencial pedagógico, e sua reverberação nos trabalhos autorais dos alunos, produzidos a partir desse encontro.

Palavras-chave: videoinstalação; pedagogia da arte; antropofagia; arte contemporânea.

\section{Abstract}

In 2012, when the Centro Municipal de Artes Hélio Oiticica, in Rio de Janeiro, was showing Dias \& Riedweg's exhibition Até que a rua nos separe, a group of high school students visited the event. Among the video installations exposed, Funk Staden (2007) particularly caught students' attention for how it updated the ancestral theme of anthropophagy but inscribed in the funk culture of the Rio de Janeiro favelas in a way that was playful, sensual and violent, at the time. We will analyze here this participative work with great pedagogical potential and its reverberation in the works of the students produced from this meeting

Keywords: video installation; art pedagogy; anthropophagy; contemporary art. 


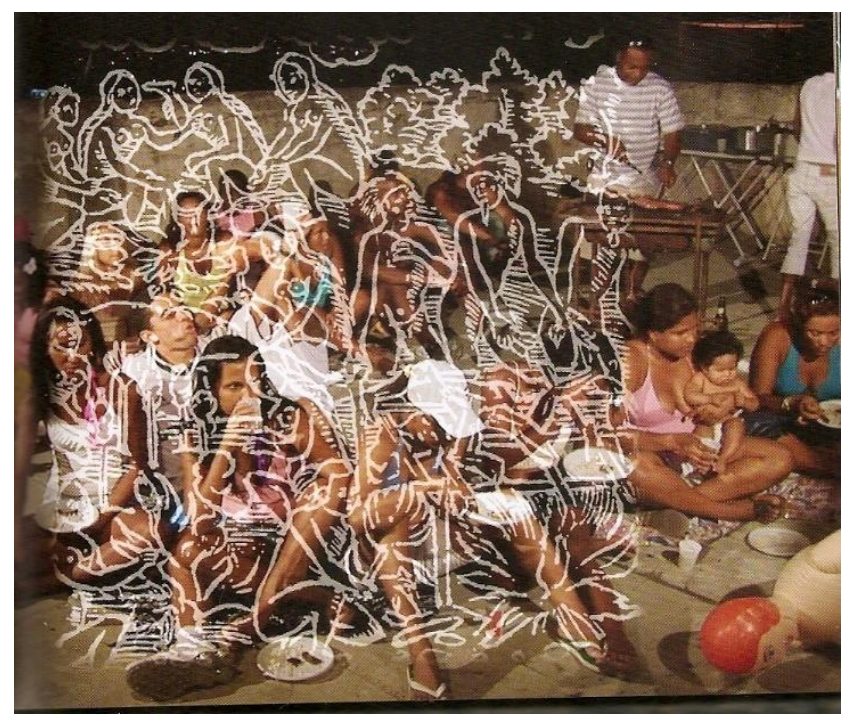

Figura 1 - Imagem da videoinstalação Funk Staden. Fonte: Fotografia disponibilizada no catálogo da mostra Até que a rua nos separe (DIAS; RIEDWEG, 2012).

Com Funk Staden (figura 1), Dias \& Riedweg voltam ao tema da antropofagia, recorrente na arte brasileira pelo menos desde os anos 1920. Agora, a questão é retomada num contexto inteiramente contemporâneo, o da festa na laje. Já em seu título carnavalesco e provocador, Funk Staden reúne em torno de um problema estético e político comum dois universos distantes um do outro: a cultura funk e Hans Staden, aventureiro alemão capturado pelos Tupinambás em 1954 que escapou, por pouco, de ser sacrificado num ritual antropofágico. O desafio colocado pela obra de Dias \& Riedweg consiste em entender como a atualização do tema da antropofagia num espaço instalativo é capaz de atingir o espectador ocidental contemporâneo, sem conhecimento sobre a cultura indígena e sobre os diferentes aspectos de um ritual agonístico e arcaico, ancorado, em certos casos, na assimilação da força do inimigo por meio da deglutição de sua carne. Além de proporcionar uma imersão altamente produtiva em termos de aprendizagem da arte contemporânea, a visita à exposição desencadeou nos alunos um processo de criação que resultou em vários trabalhos nos diferentes campos das artes (videoinstalações, mas também fotografia, escultura, pintura e performance), sob a orientação da professora de Artes Visuais do colégio ${ }^{3}$. Após um estudo de Funk Staden e das interações dos alunos com essa obra, procederemos a um balanço dessa

\footnotetext{
${ }^{3}$ Greice Cohn, professora de Artes Visuais do Colégio Pedro II, do Rio de Janeiro, acompanhou seus alunos da $1^{\text {a }}$ série do ensino médio à exposição, em 2012, quando preparava sua tese, Pedagogias da videoarte: a experiência do encontro de estudantes do Colégio Pedro II com obras contemporâneas, defendida em 2016 na Faculdade de Educação da UFRJ, sob orientação de Adriana Fresquet e Anita Leandro.
} 
atividade pedagógica, concentrando-nos em alguns dos trabalhos realizados em sala de aula. Antes de retomar essas obras, propomos um retorno à própria noção de antropofagia, abordando-a em sua dimensão histórica e estética, de forma a entender melhor a proposta de Dias \& Riedweg.

\section{Tradição antropofágica}

Tal como foi definida no Manifesto antropófago, texto de 1928 do poeta, romancista e pensador Oswald de Andrade, líder do movimento modernista brasileiro e da Semana de Arte Moderna de 1922, a ideia de antropofagia aparece na arte brasileira como uma resposta a todas as formas de colonização cultural provenientes da Europa. Tanto no manifesto de 1928 quanto na retomada posterior do tema pelo cinema brasileiro, como acontece em Como era gostoso o meu francês, de Nelson Pereira dos Santos, filme de 1971, a antropofagia é abordada em sua dimensão positiva, em referência aos aspectos religiosos, políticos e culturais da prática ancestral. Ela não tem, então, nenhuma relação com o canibalismo de psicopatas, viajantes perdidos e habitantes de cidades sitiadas que inspiraram tantos filmes. Não se trata também da antropofagia bestial de indígenas ferozes, como se vê nos cannibal movies, gênero cinematográfico florescente nos anos 70 , sobretudo na Itália, cujo título mais importante é Cannibal Holocaust, de Ruggero Deodato (1980). A antropofagia, tal como a concebe a arte brasileira, na linha da tradição oswaldiana, se inscreve, sobretudo, no contexto das pesquisas antropológicas e etnográficas, e se situa, dessa maneira, em oposição às interpretações moralizantes herdadas dos jesuítas e colonizadores europeus, fortemente enraizadas no imaginário coletivo.

Os Tupinambás, por exemplo, cuja prática antropofágica é representada em Como era gostoso o meu francês, se situavam, de um ponto de vista moral, numa posição diametralmente oposta à do homem ocidental contemporâneo. Para alcançar a complexidade do gesto radical da antropofagia entre os Tupinambás ou qualquer outro povo indígena é preciso, primeiramente, se abrir à alteridade infinita colocada por esses povos ainda hoje desconhecidos. Quando os europeus abordam a costa da América, em 1500, vários povos praticavam a antropofagia cerimonial: os Astecas sacrificavam homens e mulheres para alimentar o Deus Sol; os Guayaki, do Paraguai, estudados por Pierre Clastres, comiam a carne de seus mortos para afastar a alma dos defuntos; os Tupinambás - povo guerreiro da costa brasileira, perto do Rio de Janeiro, que lutou contra o invasor português durante o século XVI - praticavam a antropofagia de vingança. É, então, aos Tupinambás, povos pertencentes à grande nação Tupi-guarani, que fazem referência tanto o manifesto de Oswald de Andrade quanto o filme de Nelson Pereira dos Santos. Todos os homens capturados pelos Tupinambás durante os 
combates, fossem eles brancos ou indígenas de tribos inimigas, eram executados e suas carnes comidas em rituais religiosos e comunitários, dos quais participavam todos os membros da tribo e indígenas de tribos aliadas.

Por meio do ritual antropofágico, o guerreiro vingava a morte de seus ancestrais, concluindo um trabalho de luto e também de afirmação social, pois antes de se se casar, o jovem Tupinambá precisa ter capturado ou matado pelo menos um inimigo. Às vezes, a imolação do prisioneiro acontecia vários meses ou anos depois de sua captura e, nesse caso, ele podia se casar com uma mulher da tribo, geralmente a filha ou a irmã daquele que o havia capturado. Era, então, um casamento de honra para os dois lados da guerra. O prisioneiro vivia em liberdade e, caso fosse um indígena, jamais pensaria em fugir. Ao contrário do prisioneiro branco, o prisioneiro indígena compartilhava a mesma cultura antropofágica com aqueles que o haviam capturado. Ele sabia que sua morte seria, por sua vez, vingada por seu povo e, por isso, antes de morrer, provocava os inimigos, dizendo-Ihes que ele próprio havia, diversas vezes, comido a carne de seus ancestrais.

A guerra era o destino dos homens e seu único objetivo era constituir prisioneiros para a realização do rito ancestral de vingança. Então, a morte por canibalismo era um risco para todo e qualquer guerreiro. Assim, desde pequenas, as crianças eram convidadas a participar dos ritos antropofágicos. Elas eram levadas "a tocar o corpo, extirpar as entranhas e se lambuzar de sangue", de forma a adquirir coragem para a guerra e aprender a maneira mais conveniente de tratar os inimigos. Havia, entre os Tupinambás, uma verdadeira "pedagogia da vingança" (CLASTRES, 1972).

\section{Do livro de Staden ao manifesto de Oswald}

Tomado por um português, com quem os Tupinambás estavam em guerra, Staden foi mantido em cativeiro por nove meses, enquanto aguardava seu sacrifício num ritual antropofágico. Mas ele escapou desse destino ao convencer os Tupinambás de que as catástrofes naturais (tempestades, doenças) ocorridas desde a sua chegada se deviam à ira dos deuses contra a sua prisão. ${ }^{4}$ Ele retorna, então, à Europa e publica, em 1557, um livro com o relato de sua aventura, intitulado Verdadeira história e descrição de um país habitado por homens selvagens, nus, ferozes e antropófagos, situado no novo mundo chamado América. Por ter conseguido se salvar, o autor se considerava

\footnotetext{
${ }^{4}$ A salvação de Staden se deveria também, segundo a etnologia, à sua falta de bravura, o que teria desestimulado os Tupinambás a incorporarem partículas de sua pessoa. Essa recusa dos indígenas em sacrificar o prisioneiro de guerra contradiz o clichê da selvageria e assinala, naquela tradição, uma política de relação cultural com o inimigo (DIAS \& RIEDWEG, 2012: 74).
} 
um instrumento da providência divina e, por isso, sua obra, publicada durante a Reforma e a Contrarreforma, teve um grande sucesso na Europa, sendo imediatamente traduzida em várias línguas. E apesar do tom às vezes místico do texto escrito em primeira pessoa, a obra de Staden não deixa de ser o primeiro documento científico sobre o canibalismo entre os indígenas da América.

Staden descreve a antropofagia como sendo uma conduta ritual organizada e regida por leis, lembrando sempre aos seus leitores que ele conta somente aquilo que viu e ouviu. Trata-se, com efeito, de um relato de uma experiência vivida e compartilhada, sem nenhum julgamento de valor sobre a antropofagia. Impresso em Marburgo, na Alemanha, o livro foi ilustrado com 50 pranchas representando cenas do cotidiano dos Tupinambás, algumas delas retomadas, como vamos ver, na instalação Funk Staden. Nessas pranchas pode-se ver representações da antropofagia, mas, também, da pesca, da caça, da fabricação de bebidas, da maneira de dormir etc. Se comparado à visão barroca e fantástica da antropofagia que dominava, então, a iconografia europeia, o livro de Staden constitui, de certa forma, uma investigação etnográfica avant la lettre.

A iconografia do ritual antropofágico proposta por Staden representa uma mudança radical na percepção do homem americano pelos europeus. A lei que regulamentava, então, o processo colonizatório proibia matar os indígenas, ao mesmo tempo que incentivava o extermínio de todos aqueles que praticassem o canibalismo. Em tal contexto político, o livro de Staden aparecia como uma primeira tentativa de conhecimento do tabu da antropofagia. E podemos dizer que ele participa, ainda, do questionamento de sua própria civilização, por parte do homem da Renascença. É assim que, duas décadas mais tarde, em seu consagrado ensaio sobre o canibalismo, Michel de Montaigne pôde atacar a ferocidade do homem branco, numa clara referência às técnicas de tortura em vigor na Europa da época, em particular nos tribunais eclesiásticos:

\begin{abstract}
"Eu penso, diz ele, que há mais barbárie em comer um homem vivo do que em comer um morto; em dilacerar, por meio de tormentos e torturas, um corpo ainda pleno de sentimentos, assando-o no fogo ou livrando-o às mordidas de cães e porcos (como nós não apenas lemos, mas vimos recentemente, não entre inimigos antigos, mas entre vizinhos e compatriotas, e, o que é pior, sob o pretexto de piedade e de religião), do que em assá-lo e comê-lo depois de morto" (MONTAIGNE, 1965).
\end{abstract}

Antes de passar à análise de Funk Staden, é preciso situar historicamente o Manifesto antropófago de Oswald de Andrade. Assim como o surrealismo, o dadaísmo e o expressionismo, na mesma época, o modernismo brasileiro 
proclamava o retorno da arte ao primitivismo. Mas tratava-se de um "primitivismo nativo" (NUNES, 1970: xiv), bem mais radical que o primitivismo da forma dos cubistas, pois não era a arte primitiva que interessava aos modernistas, mas o "sobressalto étnico" (NUNES, 1970: xiv) que ele seria capaz de produzir no homem civilizado do começo do século XX. Mais do que uma forma, a antropofagia já era vista por Oswald de Andrade como uma Weltanschauung, uma "visão de mundo", ou seja, uma maneira de pensar que caracterizaria a fase primitiva de toda a humanidade. Seu manifesto opõe ao pensamento culto, utilitarista e domesticado ocidental um pensamento selvagem, mítico e poético. Inspirado na cerimônia guerreira do povo Tupi-guarani, ele propõe, na base do processo de criação, a assimilação desse inimigo "imaterial e proteico" (NUNES, 1970: xiv) que é o homem civilizado. O retorno ao gesto antropófago deveria permitir à arte brasileira assimilar a cultura europeia, produzindo, ao mesmo tempo, em relação a ela, uma necessária ruptura. O brasileiro, que desde o início da colonização havia importado da Europa uma visão de mundo, passaria, a partir daí, a exportar sua cosmovisão tupiniquim. É assim que o antropólogo Viveiros de Castro sugere a existência de uma linhagem, de uma comunhão de pensamento, que se estenderia de Oswald de Andrade a Guimarães Rosa, passando por Clarice Lispector, tradição capaz de colocar em circulação, precisamente, uma visão de mundo. Falar de "pensamento antropofágico não é a mesma coisa que falar de índio comendo gente. É outra coisa e esses autores estão pensando isso" (LAMBERT; BARCELLOS, 2012: 263).

Depois dos modernistas, a questão da antropofagia voltaria à tona com todo o vigor no contexto do Cinema Novo. O filme Como era gostoso o meu francês (Nelson Pereira dos Santos, 1971), por exemplo, é totalmente falado num "pseudo" tupi-guarani, língua morta, majoritária na América do Sul no século XVI e reinventada por Nelson Pereira dos Santos e sua equipe de roteiristas, da qual fazia parte Humberto Mauro. Passadas quatro décadas da realização do filme, Dias \& Riedweg retomam, em Funk Staden, a narrativa autobiográfica de Hans Staden, mostrando a atualidade do tema da antropofagia na cultura brasileira.

\section{Antropofagia de Funk Staden}

Funk Staden é uma obra concebida a partir da reunião de dois contextos socioculturais, dois momentos da história do Brasil, separados por 450 anos: o momento da chegada dos europeus, evocado pelas referências da videoinstalação ao livro de Hans Staden, e o mundo do funk carioca, filmado pelos artistas. A justaposição desses dois tempos históricos, tão inusitada quanto eficaz para o entendimento da sobrevivência das forças irracionais ao longo dos tempos, é articulada de forma a 
provocar no espectador-participante uma releitura crítica da história. O tema da antropofagia perpassa essas diferentes épocas, se manifestando tanto no conteúdo quanto na forma da videoinstalação.

É possível traçar um fio ligando a concepção de antropofagia na obra de Dias \& Riedweg à forma como ela aparece em Oswald de Andrade e no modernismo brasileiro do início do século XX, passando, mais tarde, na década de 1960, por Nelson Pereira dos Santos, já mencionado, ou, ainda, por Glauber Rocha, em História do Brasil (1973) ou por Arthur Omar, em Triste trópico (1974). Em dois momentos-chave da história da arte brasileira - modernismo e cinema novo -, a noção de antropofagia emerge como um retorno do pensamento criador aos aspectos religiosos, políticos e culturais das sociedades nacionais primitivas. $O$ gesto antropofágico ressurge como resposta das artes brasileiras a um processo colonizatório ainda vigente na atualidade. É assim que, quase um século depois dos modernistas e meio século depois dos cinemanovistas, Dias ainda vê na antropofagia, tal como enunciada no manifesto oswaldiano, "um legítimo processo de alteridade, uma forma mais intuitiva e gutural de relacionamento cultural" (DIAS; RIEDWEG, 2012: 154).

Em Funk Staden, a antropofagia é citada e retomada, tanto na proposta inicial dos artistas - o convite feito a um grupo de funkeiros para reencenar as imagens do livro de Staden - quanto na organização temporal e espacial do material reunido. As ilustrações do livro de Staden, construídas do ponto de vista do Outro, o europeu, são agora apropriadas pelos funkeiros e associadas ao projeto de criação dos artistas. $O$ gesto antropófago, fundado numa estratégia criadora que passa pela apropriação e assimilação do Outro, atravessa assim toda a obra de Dias \& Riedweg. E isso acontece não apenas porque a antropofagia é o tema central dessa videoinstalação, mas, sobretudo, porque o ritual primitivo é, ali, associado ao próprio gesto criador. A cultura antropofágica é evocada na própria construção da mise-em-scène e no projeto de montagem da obra: os funkeiros assimilam as imagens do livro de Staden e a reinterpretam com um outro tipo de coreografia - contemporânea, certo, mas carregada de gestos primitivos; ao mesmo tempo, a montagem da videoinstalação, ou seja, a distribuição dos materiais no ambiente expositivo, oferece ao visitante a possibilidade de uma adesão simbólica a um novo ritual mostrado na imagem, composto de dança e churrasco na laje. Esse duplo retorno à antropofagia, no conteúdo e na forma, desperta no espectador um novo olhar sobre as culturas ali retratadas e, especialmente no caso do espectador brasileiro, um olhar sobre si mesmo, sobre seus ancestrais.

A problematização das duas visões de mundo abordadas por Oswald - a visão primitiva e a do ocidental - está, assim, presente na própria gênese Funk 
Staden. A aproximação dos sistemas de pensamento do início da colonização brasileira e dos morros cariocas de hoje revela, segundo Dias e Riedweg,

mecanismos de dominação cultural e de perpetuação do imaginário europeu sobre os trópicos selvagens (o paraíso imaginado do Novo Mundo), bem como a instauração de cenas políticas culturalmente ainda vigentes, que legitimaram o genocídio dos índios brasileiros e a usurpação enquanto metodologia governamental, durante a colonização do continente americano. (DIAS; RIEDWEG, 2012: 70)

Essa videoinstalação possibilita pensar o encontro com a arte como sendo também um encontro com o Outro, uma descoberta da alteridade; ela permite pensar a representação e a ação dos corpos como um lugar político, de interação e compartilhamento. Vejamos como isso se realiza, na prática, no espaço instalativo.

Funk Staden ocupa um espaço octogonal, com aproximadamente sete metros de diâmetro, composto por seis telas, cada uma com cerca de 2 metros de altura por 3,5 metros de largura. As duas outras faces do octógono são formadas por dois vãos, para entrada e saída do público. Três dessas telas se destinam à projeção de imagens, enquanto as outras três, de vidro escuro e transparente, se prestam, ao mesmo tempo, à visualização do espaço circundante da exposição e a refletir os corpos dos visitantes. Para receber os estímulos visuais provenientes das três telas de projeção, de forma simultânea e alternada, o espectador precisa se movimentar continuamente no espaço. Ao fazer isso, ele se depara com imagens de seu próprio corpo e dos demais espectadores refletidas nas telas de vidro.

No início das projeções, vê-se três imagens diferentes, distribuídas nas três telas. A primeira mostra uma laje do morro Dona Marta durante o dia, imagem sobre a qual se inscreve, em caixa alta, o título da obra: FUNK STADEN. Nas outras duas telas, figuram mapas ilustrados do livro $A$ verdadeira história dos selvagens, de Hans Staden. Seguem-se imagens de páginas gastas do livro de Staden e, depois, a animação de uma ilustração extraída do mesmo livro, uma imagem do ipirapema, arma ritual decorada por mulheres tupinambás utilizada para dar o golpe mortal nos prisioneiros a serem sacrificados. A figura do ipirapema gira nas três telas, desenhando no ar uma espécie de túnel do tempo, que aspira o visitante da instalação.

Cenas de bailes funk são, então, sobrepostas ou justapostas às gravuras do livro de Staden. O baile nasce, assim, das imagens dos Tupinambás, como se as poses dos indígenas nas gravuras dessem origem às posturas corporais do funk. O movimento espiral do ipirapema é repetido pelo rebolado dos corpos que dançam sobre a laje e por uma engenhoca de madeira e palha em formato de mastro giratório, construída pelos artistas e carregada por uma das dançarinas. Esse objeto - uma espécie de steadicam 
primitivo e artesanal - serve de suporte para três câmeras. Nas mãos da funkeira, ele percorre o espaço da coreografia, produzindo imagens giratórias. A cena do baile funk captada por esse dispositivo reitera um perpétuo movimento circular. Não se pode deixar de pensar no cine-olho vertoviano, que "penetrando no caos aparente da vida (...) busca encontrar, na própria vida, a resposta para o tema abordado" (VERTOV, 1972: 127). Ao associar a arma do sacrifício ao próprio recurso técnico de filmagem, o objeto criado por Dias e Riedweg chama atenção para a íntima relação entre imagem e morte, mas, também, entre tecnologia e artesanato.

Nas cenas seguintes, os funkeiros desenvolvem uma coreografia fortemente inspirada nas xilogravuras ilustrativas do capítulo 29 da edição original do livro de Staden. Essas imagens, criadas a posteriori, na ocasião da edição do livro, mediante relato de Staden ao gravurista, são ricas em detalhes sobre o ritual antropofágico. As gravuras mostram, por exemplo, pedaços de um corpo humano esquartejado, dispostos numa grelha sobre uma fogueira (figura 2). A videoinstalação aproxima essas cenas do século XVI das cenas do churrasco na laje. A gravura de uma cabeça pousada sobre um caldeirão é montada em raccord com imagens de bocas que mastigam a carne do churrasco. Em roda, como os Tupinambás das gravuras, os funkeiros, de pernas abertas, saltam sobre os pedaços do corpo nu de um manequim de plástico, cujo sexo pega fogo. Da fogueira da aldeia indígena das gravuras passa-se, na tela sobreposta, à fogueira da laje, onde, sobre a churrasqueira, uma faca fende delicadamente a pele dilatada de uma salsicha grossa e fumegante. A reunião dos dois universos culturais sob o signo do rito antropofágico encontra sua síntese na música e na dança erótica e, às vezes, deliberadamente pornográfica dos funkeiros.

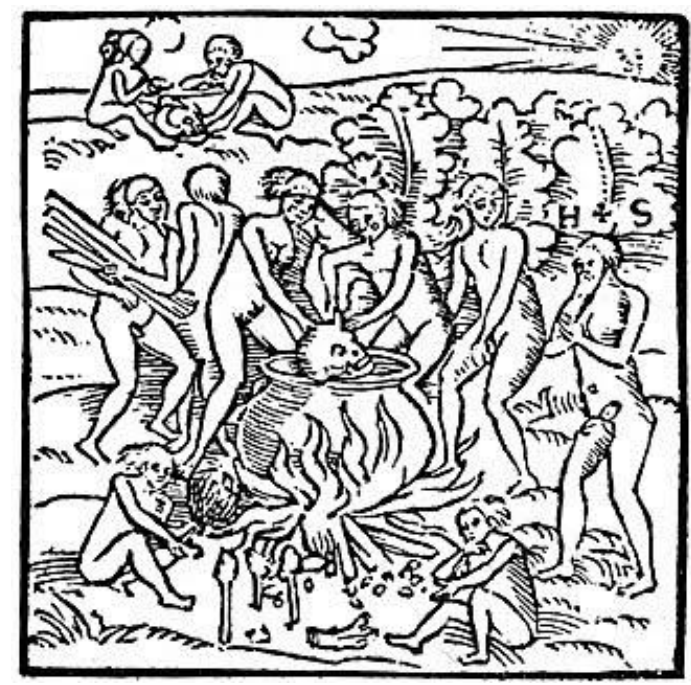

Figura 2 - Ilustração do livro de Hans Staden. Fonte: CHIMICATTI, 2010. 
No início dos planos de Dias \& Riedweg, os dançarinos aparecem imóveis, como se, interrompidos no meio de um gesto, tivessem sido transformados em estátuas. Suas posturas corporais e a disposição do grupo em círculo, às vezes em torno da fogueira, remetem, evidentemente, ao conteúdo das gravuras de Staden (figura 3). Após alguns segundos de imobilidade, eles começam a dançar, sempre em círculo. Como num tableau vivant, a cena filmada adquire um tom performativo. Dias diz, inclusive, ter se surpreendido com as performances dos funkeiros. E Riedweg, ao rever o material filmado, descobriu um aspecto da realidade ainda "mais realista do que a representação do horror da favela" (DIAS; RIEDWEG, 2012: 180).

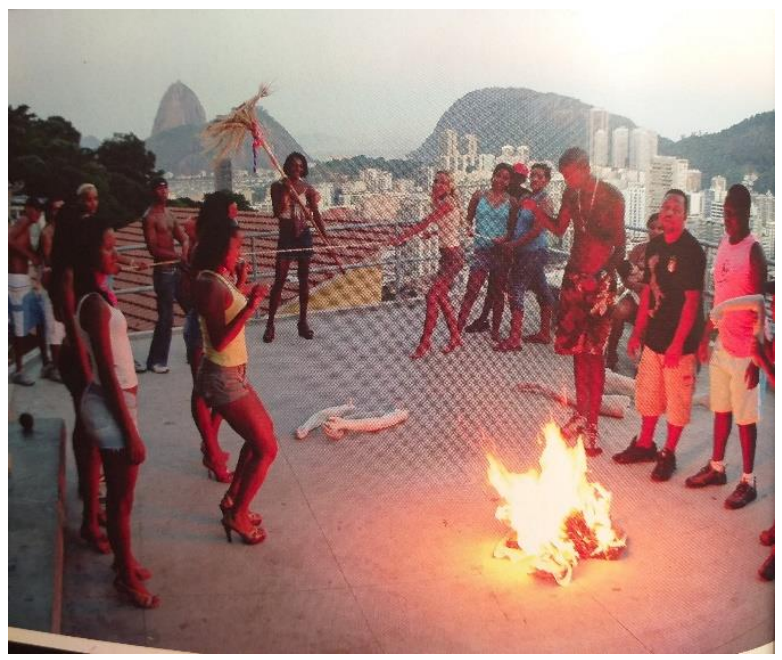

Figura 3: Imagem da videoinstalação Funk Staden. Fonte: Fotografia disponibilizada no catálogo da mostra Até que a rua nos separe. (DIAS; RIEDWEG, 2012).

Mesmo que essas encenações tenham acontecido num espaço teatral, permitindo um distanciamento irônico em relação ao real, ali, "qualquer coisa podia acontecer" (DIAS; RIEDWEG, 2012: 180). O deboche, o erotismo e a violência da performance, em diálogo com as gravuras do século XVI, remetem à persistência de um estado primitivo e arcaico, que atravessa gerações e culturas, até chegar ao presente. Há, em Funk Staden, um procedimento semelhante ao método warburguiano (2012) de abordagem antropológica das imagens, vistas, pelo historiador da arte, como matéria orgânica que armazena patologias humanas, forças irracionais, testemunhos sobre tensões ancestrais, vestígios, enfim, com vida póstuma - imagens portadoras de um potencial mnêmico que as torna capazes de reagir a estímulos ao longo do tempo. Não é outra a função do texto de Staden na videoinstalação. Carregado de memória, o livro volta às três telas de Funk Staden e, lentamente, as ondulações de suas páginas se fundem com imagens das ondas do mar na costa brasileira, onde aportaram as naus 
europeias em plena guerra entre portugueses e tupinambás. Um vai-e-vem incessante entre passado e presente evoca no espectador de Funk Staden uma longa e interminável história de encontro com o Outro, uma história de assimilação e, também, de extermínio.

Na pista sonora, ouve-se a letra de uma canção conhecida, de 1995 - O rap da felicidade, de Cidinho e Doca - uma elegia à dignidade, ao pertencimento e à alegria: "eu só quero é ser feliz, andar tranquilamente na favela onde eu nasci, e poder me orgulhar de ter a consciência que o pobre tem seu lugar". A letra da música reforça o tema da alegria da festa e produz um curto-circuito de culturas que integra 0 espectador, pois todo visitante está sujeito a fazer, pelo menos, um passo de funk na grande pista de dança criada pelos artistas, no centro das seis telas.

As imagens de Funk Staden, sua espacialização, sua montagem, a convocação do corpo do espectador no momento de apreensão da obra, tudo isso remete às complexas relações entre identidade e alteridade na formação da cultura brasileira, processo histórico desencadeado de fora para dentro, em meio a distorções que permanecem ainda hoje no imaginário nacional. O espectador brasileiro, situado entre as imagens projetadas e os reflexos de si mesmo nas telas transparentes, se descobre entre dois mundos. Sensações de distanciamento em relação às imagens projetadas (o espectador não pertence aos Tupinambás) se misturam com o sentimento de pertencimento (o funk é parte de sua cultura cotidiana). Entre estranhamento e familiaridade, ele vê a instalação de dentro e de fora dela, simultaneamente. Nesse entre-dois em que se instalam os visitantes da obra, Dias \& Riedweg (2012: 72) formulam um pensamento instigante sobre a constituição identitária e cultural do povo brasileiro. Eles reconhecem que "o outro e a cultura do outro sempre foram e serão oficialmente reconhecidos através do mero exercício de percepção de quem ou o quê os legitima e os torna um dado histórico". Ao se ver em meio a um ritual de dança, o espectador de Funk Staden entende que o exotismo é produto de uma "alteridade manipulada ou incompleta", de uma cultura de gueto mal compreendida.

Em Funk Staden, o funk não é algo exótico e não pertence à cultura do Outro. Ele se confunde, ao contrário, com um rito ancestral e possui uma carga mnêmica que pode ser reativada pelos visitantes. Ao entrar na instalação, é como se o espectador entrasse num baile. A performance antropófaga representada na imagem se prolonga na imensa pista vazia e escura do espaço instalativo, que convida a bailar. Estrategicamente, a obra não prevê lugares para se sentar e descansar. Todos os momentos da instalação devem ser vividos de pé, como os personagens da laje e os indígenas em volta do caldeirão antropofágico. Para os artistas, Funk Staden é

uma forma de ação teatral que sobrepõe 450 anos na mesma costa do Brasil, produzindo uma espécie de delírio que deixa 
a retina oscilando entre o passado e o agora, e que permite ao espectador ocupar um terceiro lugar fora e dentro dela. Aqui, o ato da vivência da obra pelo espectador se move dentro e fora do território mental e espacial dela. (DIAS; RIEDWEG, 2012: 156)

Como pode se situar o jovem espectador brasileiro, muitas vezes frequentador de bailes funk, em relação a uma encenação que associa sua própria cultura à história de Hans Staden? Como reage seu corpo à coreografia dos funkeiros do Morro Dona Marta e ao ritual dos Tupinambás? Que pulsões nele provocam a comilança lasciva de churrasco de boi na laje e o transe místico dos personagens de Staden frente a um corpo humano esquartejado? Que lembranças despertam esses ritos culturais? Que pensamentos ocorrem ao espectador diante dessa multiplicidade de imagens e encenações? Que histórias, que mundos essas imagens evocam? Como outras formas contemporâneas da arte, que se dedicam cada vez mais ao que Rancière (2012: 77) chamou de "inventário unanimista dos vestígios de comunidade", de "gestos arquetípicos e grandes ciclos da vida humana", Funk Staden, ao aproximar imagens e mundos separados no tempo e no espaço, estimula novas figurações e associações na percepção espectatorial, que produzem efeitos de "copertencimento"5.

Se Dias e Riedweg pretendiam, com as aproximações de imagens anacrônicas, provocar, no público brasileiro, um estranhamento em relação à sua própria construção identitária, a performatividade resultante da interação entre os corpos no espaço instalativo problematiza e potencializa essa provocação, ao permitir a adição de mais uma camada reflexiva à obra, graças ao jogo de encenação. No espaço octogonal da instalação, os diálogos entre diferentes tempos e culturas mostram que todos os sujeitos ali implicados - os Tupinambás e seus rituais; Hans Staden e suas memórias; Dias \& Riedweg e sua leitura da antropofagia; os funkeiros e sua coreografia a partir das gravuras; e, finalmente, o público, interpretando e interagindo à sua maneira com tudo o que é mostrado - se veem envolvidos numa relação de alteridade, em que o observador se nutre do Outro observado e se recria (ou cria algo, ou é recriado) a partir desse encontro. A obra encarna, portanto, em seu próprio processo constitutivo, o espírito antropófago. Nas palavras dos artistas, "o problema dessa obra deriva do fato de todo mundo vê-la como um espelho, um espelho antropofágico" (DIAS; RIEDWEG, 2012: 188-190).

No cerne da instalação de Dias \& Riedweg encontra-se, como mencionamos, a questão da alteridade e do encontro com o Outro, do gesto antropofágico e da

\footnotetext{
${ }^{5}$ Rancière (2012: 68) compara a montagem dialética e a montagem simbólica, identificando nessa última uma máquina de mistério que, em vez de opor mundos, põe em cena, por meios imprevistos, um sistema de copertencimento.
} 
ressignificação desse mesmo gesto na atualidade. O diálogo crítico estabelecido com as imagens e os diferentes contextos históricos por elas evocados fazem bem mais do que, simplesmente, integrar o espectador à obra, por meio da dança. Ao aderir à proposta de Funk Staden, o visitante deixa de ser espectador para penetrar num terreno desconhecido, o das pulsões animais, que nenhum conhecimento intelectual prévio sobre a história da arte poderia explicar racionalmente. É por isso que os alunos do curso de artes do Pedro II, ao visitarem a exposição, se surpreenderam tanto com as relações estabelecidas por eles com as imagens. Funk Staden produz no espectador não apenas o deleite intelectual da descoberta de uma forma que pensa e faz pensar, como propõe Godard nas História(s) do cinema (1988-1998), mas, sobretudo, o tema abordado e a maneira de abordá-lo, que beira o documentário, mergulha o visitante no impensado deleuziano (1990), proporcionando a confrontação direta com um mundo irracional que concerne os dois polos da imagem, o da criação e o da recepção.

\section{Pedagogia da videoarte}

As videoinstalações operam transformações nos modos de recepção habituais, despertando no espectador novas maneiras de se posicionar diante de uma obra. O convite da videoinstalação a uma atitude diferenciada, participativa, provém, principalmente, da espacialização desse tipo de obra e das operações de montagem ali envolvidas. Ao adentrar um espaço instalativo permeado de intervalos, que the oferece um percurso propositadamente flutuante, o espectador é incluído no processo, ainda em curso, de construção de sentido da obra. A videoinstalação lança o espectador num jogo performático de representação que demanda não apenas do espírito, mas também do corpo, uma postura ativa. Além da organização não linear do espaço, a distribuição das imagens numa instalação também implica em escolhas por parte do espectador, multiplicando, assim, as possibilidades de associação e ordenação dos materiais utilizados na montagem da obra.

Vem daí a pedagogia de Funk Staden e a consequente adesão do espectador ao rito proposto pela obra. Uma dimensão pedagógica da instalação diz respeito à sua própria forma: trata-se de uma obra musical e dançante, o que, de antemão, pressupõe o compartilhamento do espaço entre os visitantes por meio da dança, da festa e das diferentes interações proporcionadas pela performance coletiva por ela suscitada. Como acontece numa sala de aula, em relação ao conhecimento, a descoberta da obra passa por uma atividade heurística eminentemente coletiva. Outro aspecto da pedagogia de Funk Staden está relacionado ao conteúdo da obra: a antropofagia, evocada nas gravuras do século XVI retomadas na instalação, religa o espectador a um passado indígena desconhecido e aos diferentes estratos temporais e camadas históricas de sua 
própria cultura. Se, como vimos anteriormente, a forma favorece o compartilhamento de uma mesma performance no espaço da obra, o conteúdo, por sua vez, convida a uma tomada de posição política em relação ao tempo histórico, uma vez que a narrativa estabelece ligações entre cultura funk e cultura indígena, trazendo à superfície um longo processo de extermínio dos povos originários e dos afrodescendentes, ainda em curso.

Na visita à exposição de Dias \& Riedweg, os adolescentes do curso de Artes Visuais do colégio Pedro II se posicionaram no meio das projeções e, graças à transparência dos vidros, seus corpos dançantes podiam ser vistos por quem estava fora do espaço instalativo. Isso produzu efeitos surpreendentes, pois seus corpos se misturavam aos corpos dos Tupinambás e dos funkeiros. Sombras, silhuetas e posturas dos estudantes se fundiam com as atitudes corporais dos funkeiros e dos indígenas das gravuras. Numa dança ritmada, três temporalidades podiam, assim, ser acionadas e integradas simultaneamente ao espaço expositivo, por meio de três grupos de personagens envolvidos na representação do rito antropófago: o tempo histórico que inspira a obra (o da guerra secular entre indígenas e homem branco); o momento da encenação filmada pelos artistas (vivido pelos funkeiros); e o ato de recepção e fruição da obra (vivenciado pelos espectadores participantes). Cada uma dessas temporalidades está relacionada a uma dança proveniente de um gesto antropófago específico: os indígenas rodeiam o corpo do guerreiro branco sacrificado, para assimilar sua coragem; os funkeiros devoram a cultura pornográfica e violenta produzida pela sociedade racista e segregacionista em que vivem, para dela extrair um ato de resistência, mesmo que (ou sobretudo porque) vulgar, agressivo; e o espectador, por sua vez, ocupa o espaço da obra para transformá-lo em espaço de vida, ou seja, de encontros, de trocas humanas por meio da dança. A interação e a materialização desses três tempos criam os tais "efeitos de copertencimento" de que falávamos acima e que, seguramente, surpreenderam os próprios artistas.

Destacamos, aqui, três criações coletivas de estudantes do Colégio Pedro II, realizadas em 2012, após o encontro com a obra de Dias \& Riedweg: Obra oculta, $O$ Mundo circulando e Telepresença ${ }^{6}$. Todos esses trabalhos foram concebidos em diálogo com Funk Staden. Atentos aos diferentes aspectos da obra, os estudantes buscaram desenvolver em suas criações as potencialidades dessa instalação. Em suas obras, eles exploraram os grandes princípios norteadores de Funk Staden: as possibilidades de projeção das imagens no espaço cênico da instalação; o alcance antropológico da ideia

\footnotetext{
${ }^{6}$ Os autores desses trabalhos são: Obra oculta (Sarah Lopes, Luiz Arthur Labre, Sofia dos Santos, Alexandre Vasques); O Mundo circulando (Wallace Araújo, Thatianna Gomez, Karina Santiago, Vinícius Cherfan); Telepresença (Rodrigo Nascimento, Matteus Mendonça, Paulo Araújo Vasconcellos, Lucas Barcellos).
} 
de circularidade; e a abolição das fronteiras temporais e espaciais entre a arte e a vida, a obra e o espectador.

Obra oculta (figura 4), videoinstalação concebida por um grupo de quatro estudantes, chama atenção por sua sofisticada espacialização das imagens e o desenvolvimento de novas possibilidades de projeção. Trata-se de um vídeo monocanal, com imagens em looping do tampo de uma mesa coletiva da sala de artes projetadas sobre o tampo de uma outra mesa de trabalho, menor, a da carteira individual de sala de aula. Meta-imagem, Obra oculta mostra uma mesa dentro de outra mesa: a grande mesa coletiva da sala de artes, em torno da qual os estudantes se sentam para assistir às aulas e fazer seus trabalhos, projetada na mesinha de trabalho individual. A mesa da sala de artes é antiga e bastante danificada, com buracos feitos por cupins e pés que necessitam de calços para se manter em equilíbrio. Mas, apesar de seu estado de conservação precário, ela exerce grande atração sobre os estudantes, devido ao aspecto de sua superfície, totalmente pichada, assinada e desenhada com lápis, caneta, canetinhas hidrográficas, corretivos etc. Essas pichações tecem na superfície de madeira um emaranhado de linhas e manchas sobrepostas, como um palimpsesto em permanente construção. Para além da infração simbólica do deslocamento da mesa de artes para o espaço controlado da sala de aula, onde a pichação é proibida, Obra oculta procede, ainda, a um trabalho de memória, pois sobre a mesa da sala de artes estão os vestígios da passagem de outros alunos por ali. Ao tomar emprestado de Funk Staden sua estratégia de multiplicação das superfícies de projeção (os corpos dos funkeiros e dos visitantes da exposição, no caso da obra de Dias \& Riedweg), Obra oculta explora, como podemos ver, o potencial mnêmico do recurso cênico da instalação.
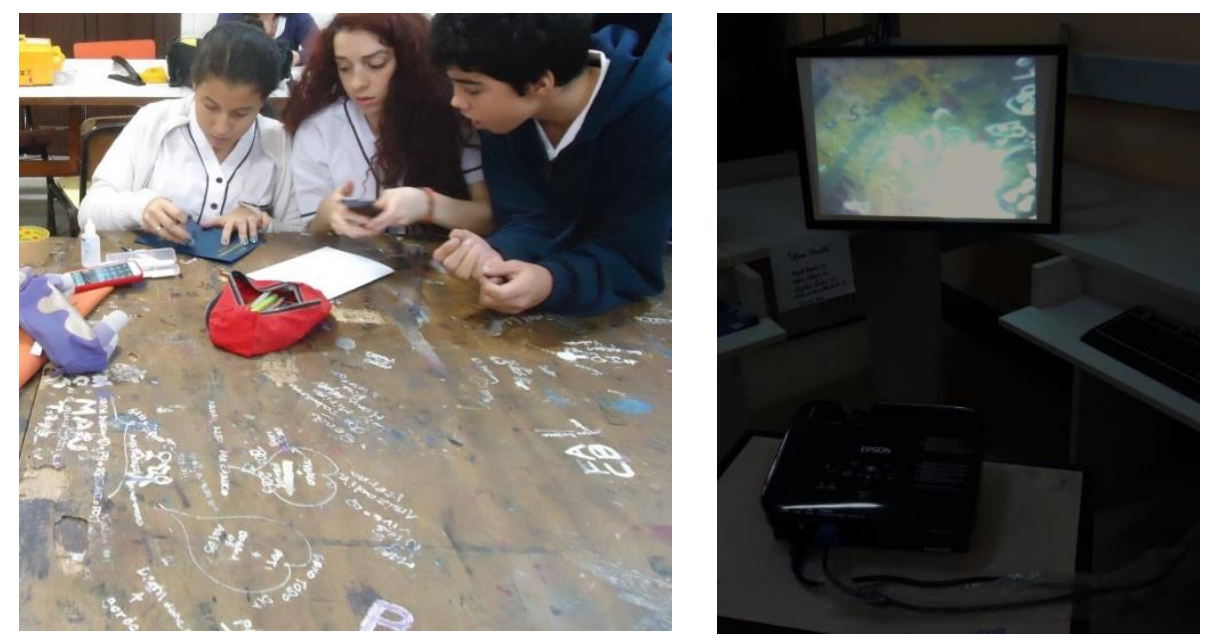

Figura 4 - Alunos trabalhando sobre a mesa da sala de Artes (2014) e a videoinstalação na exposição. Fonte: Fotografias de Greice Cohn. 
O Mundo circulando (figura 5), por sua vez, se destaca pelo dispositivo de filmagem especialmente criado para a exploração de movimentos circulares. Uma bicicleta passeia pelo calçadão de Copacabana com uma câmera digital presa à roda traseira, onde foi amarrada com um cadarço. Motivados pela imprevisibilidade dos resultados, os alunos criam uma operação experimental e de risco para o próprio dispositivo (a câmera acabou se quebrando). A partir da imagem de uma paisagem conhecida do Rio de Janeiro - a praia de Copacabana - e de um som igualmente conhecido - uma versão instrumental de Garota de Ipanema -, o vídeo produz, na verdade, graças ao dispositivo de filmagem, uma ruptura radical com o cartão postal evocado. Tudo é posto em circulação: céu e terra, mar e nuvens, asfalto e calçada, o olhar do espectador e a imagem clichê das praias cariocas. Passam ciclistas, transeuntes, atletas, patinadores. O eixo da imagem circula durante o travelling da bicicleta, colocando a praia e a calçada de cabeça para baixo. A composição da paisagem e o olhar do espectador se desestabilizam. A busca pelo reconhecimento do lugar comum cede espaço ao deleite de descobrir novas paisagens, repletas de grafismos e geometrias inesperadas. O Mundo circulando faz o olhar do espectador rodopiar diante de linhas, cores e formas sempre renovadas, num hipnótico balé giratório de imagens caleidoscópicas. Como o rodopio do ipirapema dos indígenas ou o steadicam improvisado dos funkeiros em Funk Staden, a câmera em transe de O Mundo circulando coloca, de certa forma, o espectador no movimento do caos.

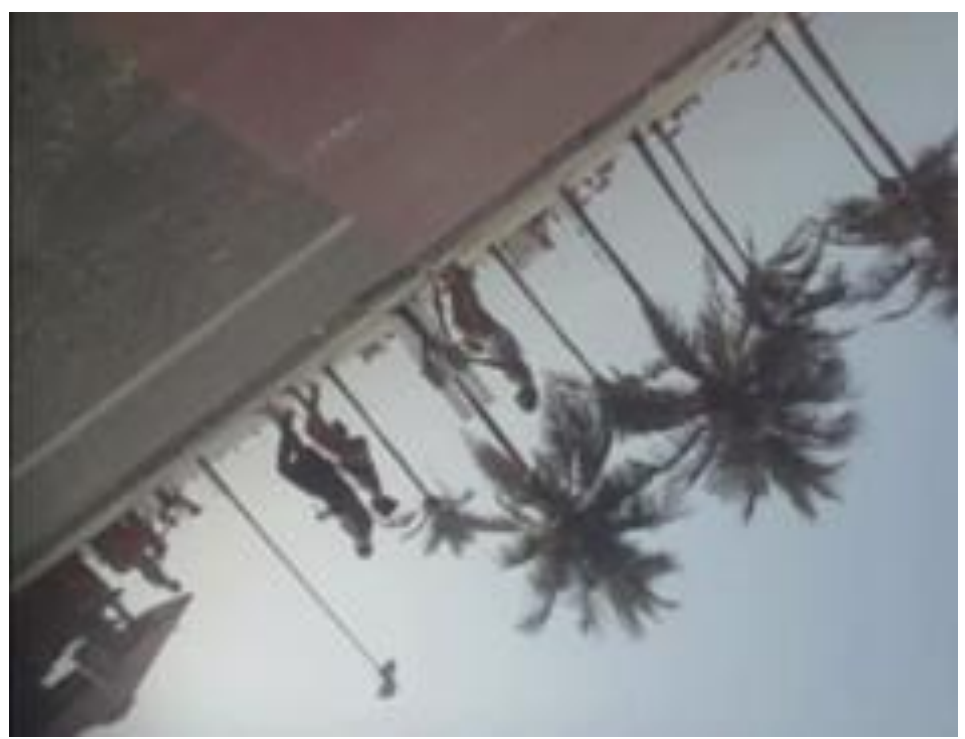

Figura 5 - Imagem do vídeo O Mundo circulando. Fonte: Frame do vídeo extraído por Greice Cohn. 
Por fim, Telepresença (figura 6), em seu diálogo com Funk Staden, prioriza a criação de condições para a participação do espectador. Uma cadeira de praia é colocada em frente à parede sobre a qual são projetadas imagens da praia de Ipanema, filmada pelos estudantes do ponto de vista de quem está sentado na areia, de frente para o oceano. As imagens mostram as pessoas na praia, com o mar ao fundo. $\mathrm{Na}$ junção entre o chão e a parede foi colocada areia de praia, de forma a produzir uma continuidade entre espaço virtual e espaço real. O espectador é convidado a se sentar na cadeira e a ficar olhando a praia, confortavelmente. Uma vez cedendo a esse apelo, ele percebe sua sombra projetada na tela, sobre a imagem da praia. Um projetor instalado atrás da cadeira de praia faz com que a imagem do visitante incida exatamente sobre a paisagem por ele observada e que ele passa, agora, a habitar, junto com as silhuetas dos banhistas, como se ele também tivesse sido filmado naquela praia. Além do espectador sentado, os que estão de pé também são capturados pela projeção e incluídos na imagem; suas sombras se projetam na areia da praia, assim como a sombra dos banhistas filmados. Mas não se trata, aqui, da produção de um mero efeito ilusório de imersão. Na verdade, o que essa videoinstalação produz é a coincidência (ou coexistência) entre as imagens filmadas e o momento presente, vivido pelo corpo do espectador, cuja percepção temporal e espacial se vê problematizada pelo dispositivo inclusivo de projeção. Estávamos no mês de janeiro e, devido a uma greve no ano precedente, os estudantes participavam, a contragosto, da reposição de aulas em pleno verão carioca. A presença da praia na instalação sublima, assim, um desejo de praia. Em Telepresença, graças a uma dupla operação de deslocamento e inclusão (das imagens e do espectador), a praia se torna uma real presença no espaço da exposição, ao mesmo tempo em que o espectador se projeta no espaço imagético da praia. Ao denominar seu trabalho de Telepresença, os estudantes se mostram cientes do alcance dessa operação de captura e inserção do corpo do espectador na imagem para a produção de significados. Eles produzem, de maneira instintiva, aquilo que Françoise Parfait (2001: 130) definiu, justamente, como "efeito de telepresença", que é esse deslocamento espaço-temporal produzido por uma obra quando ela se mostra capaz de colocar o espectador na presença de seu próprio corpo, numa imagem de televisão. A partir do ato de criação, ato impensado, os alunos chegaram a uma abstração conceitual muito próxima daquela produzida por Parfait. 


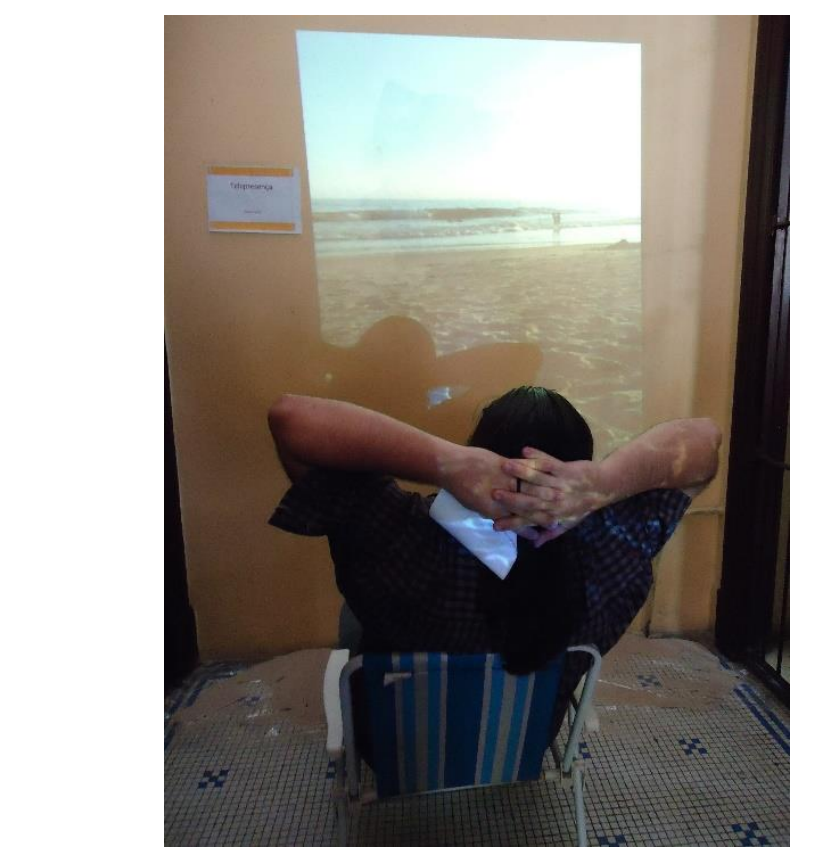

Figura 6 - Espectador interagindo com a videoinstalação

Telepresença. Fonte: Fotografia de Greice Cohn.

Nos demais trabalhos realizados pelos estudantes, várias outras proposições instalativas e operações de montagem remetem a Funk Staden. No entanto, não seria possível, aqui, comentar todas essas obras. Mas, ainda que pequena, nossa amostragem dá uma dimensão do alcance pedagógico do trabalho de Dias \& Riedweg. Inspirado numa abordagem antropofágica da arte e dos materiais, o método desses artistas pôde, exatamente por essa razão, ser apropriado e transformado pelos estudantes. Assimilada enquanto visão de mundo, a antropofagia se faz presente nas obras dos estudantes como uma citação sem aspas, ao mesmo tempo arriscada e lúdica, da obra de Dias \& Riedweg. O encontro com Funk Staden e a assimilação do gesto dos artistas, mas também dos indígenas e dos funkeiros, ativaram nos alunos uma atitude antropofágica em relação à criação artística. Os processos criativos resultantes do encontro com o Outro, proporcionados por Funk Staden, colocou-os em contato consigo mesmos e com suas respectivas potências criadoras. Além de tornar possíveis olhares diferenciados sobre a cultura brasileira e sobre os modos de representação dessa cultura, Funk Staden despertou o interesse desses jovens estudantes de arte pela videoinstalação. 


\section{Referências Bibliográficas}

ANDRADE, Oswald de. Manifesto antropófago. In: TELES, Gilberto Mendonça. Vanguarda européia e modernismo brasileiro: apresentação e crítica dos principais manifestos vanguardistas. 3 ed. Petrópolis: Vozes; Brasília: INL, 1976. Disponível em: http://www.ufrgs.br/cdrom/oandrade/oandrade.pdf. Acesso em: 14 jul. 2016.

BARBOSA, Ana Mae. A imagem no ensino da arte: anos oitenta e novos tempos. São Paulo: Perspectiva, 2007.

CHIMICATTI, Felipe Aguiar. Análise: Hans Staden em duas viagens ao Brasil e uma breve comparação com a carta de Pero Vaz de Caminha. Jornal Plástico Bolha, 8 fev. 2010. Disponível em: http://jornalplasticobolha.blogspot.com/2010/02/hans-staden-emduas-viagens-ao-brasil-e.html. Acesso em: Jun. 2019.

CLASTRES, Hélène. Les beaux-frères ennemis : à propos du cannibalisme tupinambá. Nouvelle Revue de Psychanalyse, n. 6, automne 1972. (Destins du cannibalisme)

COHN, Greice. Pedagogias da videoarte: a experiência do encontro de estudantes do Colégio Pedro II com obras contemporâneas. 2016. Tese (Doutorado em Educação) Universidade Federal do Rio de Janeiro, Rio de Janeiro, mar. 2016.

DELEUZE, Gilles. A imagem-tempo. São Paulo: Brasiliense, 1990.

DIAS, Maurício; RIEDWEG, Walter. Até que a rua nos separe. (Catálogo da mostra). Rio de Janeiro: Centro Municipal de Arte Hélio Oiticica, 2012.

HISTÓRIA(S) do cinema. De Jean-Luc Godard. Série documental em 8 partes. França: Canal+, 1989-1999.

LAMBERT, Cleber; BARCELLOS, Larissa. Entrevista com Eduardo Viveiros de Castro. In: Primeiros estudos, São Paulo, n. 2, p. 251-267, 2012. Disponível em: http://www.revistas.usp.br/primeirosestudos/article/download/45954/49556. Acesso em: jul. 2016.

MONTAIGNE, Michel de. Des cannibales. In: MONTAIGNE, Michel de. Les essais. Livre Premier. Paris: PUF, 1965.

NUNES, Benedito. A antropofagia ao alcance de todos (Introdução). In: ANDRADE, Oswald de. Obras Completas de Oswald de Andrade, Do Pau-Brasil à Antropofagia e às Utopias, vol. VI. Rio de Janeiro: Civilização Brasileira, 1970. p. xi-xvii. Disponível em: http://www.jcrisostomodesouza.ufba.br/atual01/a_atropofagia_ao_alcance.html. Acesso em: 14 jul. 2016.

PARFAIT, Françoise. Vidéo: un art contemporain. Paris: Regard, 2001.

RANCIÈRE, Jacques. O destino das imagens. Rio de Janeiro: Contraponto, 2012.

VERTOV, Dziga. L'A.B.C. des Kinoks. In: VERTOV, Dziga. Articles, journaux, projets. Paris: Union Générale d'Editions; Cahiers du Cinéma, 1972.

WARBURG, Aby. Atlas mnémosyne. Paris: L'Ecarquillé, 2012. 